\title{
PENGARUH MODEL PEMBELAJARAN MASTER BERBANTUAN MIND MAPPING TERHADAP KEMAMPUAN PEMECAHAN MASALAH MATEMATIKA SISWA SMA NEGERI 3 SINGARAJA
}

\author{
K. P. Wahyuni, N. M. S. Mertasari, I. N. Gita \\ Jurusan Pendidikan Matematika Universitas Pendidikan Ganesha \\ Singaraja, Indonesia \\ e-mail: \{wahyunip100, srimertasari, nyoman.gita\}@undiksha.ac.id
}

\begin{abstract}
Abstrak
Penelitian ini bertujuan untuk mengetahui pengaruh model pembelajaran MASTER berbantuan mind mapping terhadap kemampuan pemecahan masalah matematika siswa. Jenis penelitian ini adalah eksperimen semu dengan desain penelitian adalah Post Test Only Control Group. Populasi penelitian ini adalah seluruh siswa kelas XI MIPA SMA Negeri 3 Singaraja tahun ajaran 2018/2019. Sampel dalam penelitian ini adalah siswa kelas XI MIPA 2 dan XI MIPA 3 yang diambil menggunakkan teknik cluster random sampling. Data dikumpulkan dengan tes kemampuan pemecahan masalah matematika yang diberikan kepada siswa dalam bentuk tes uraian dan diberikan di akhir penelitian. Data hasil tes kemampuan pemecahan masalah matematika dianalisis menggunakan uji-t satu ekor dengan taraf siginifikansi $5 \%$. Hasil penelitian menunjukkan bahwa $t_{\text {hitung }}=3,606938>t_{\text {tabel }}=1,998341$ sehingga $H_{0}$ ditolak. Ini berarti, kemampuan pemecahan masalah matematika siswa yang dibelajarkan dengan model pembelajaran MASTER berbantuan mind mapping lebih baik daripada kemampuan pemecahan masalah matematika siswa yang dibelajarkan dengan model pembelajaran konvensional. Dengan demikian, dapat disimpulkan bahwa terdapat pengaruh model pembelajaran MASTER berbantuan mind mapping terhadap kemampuan pemecahan masalah matematika siswa.

Kata kunci: model pembelajaran MASTER, mind mapping, pemecahan masalah matematika
\end{abstract}

\begin{abstract}
This study aims to determine the effect of MASTER learning model supported by mind mapping to students' mathematical problem solving abilities. The type of this study was a quasi-experiment by using posttest only control group design. The population of this study is all students of class XI MIPA SMA Negeri 3 Singaraja in the academic year 2018/2019. The students of class XI MIPA 2 and XI MIPA 3 as samples were obtained by using cluster random sampling technique. Data was collected through test of mathematical problem solving abilities given to in the form of essay test and given at the end of study. Data from the test results of mathematical problem solving ability were analyzed using one-tailed t-test with a significance level of $5 \%$. The result showed $t_{\text {hitung }}=3,606938>t_{\text {tabel }}=1,998341$ that the $H_{0}$ was rejected. This means that the mathematical problem solving abilities who are taught by MASTER learning model supported by mind mapping are better than students' mathematical problem solving abilities taught by conventional learning model, so it can be conclude that there is an effect of MASTER learning model supported by mind mapping to students' mathematical problem solving abilities.
\end{abstract}

Keywords: MASTER learning model, mind mapping, mathematical problem solving

\section{PENDAHULUAN}

Pembelajaran

diharapkan

mampu

matematika

paradigma siswa terhadap kegunaan matematika dalam kehidupan. Namun, tidak mudah untuk dapat menanamkan persepsi kepada siswa bahwa matematika sangat penting dalam kehidupan. Hal ini disebabkan karena konsep matematika disajikan dalam bentuk abstrak. Marti (dalam Sundayana, 2014:3) mengemukakan bahwa obyek matematika yang bersifat abstrak tersebut merupakan kesulitan tersendiri yang harus dihadapi 
siswa dalam mempelajari matematika. Daryanto (2012:240) menyatakan matematika diberikan kepada semua siswa mulai dari jenjang sekolah dasar hingga perguruan tinggi, bertujuan untuk membekali mereka dengan kemampuan berfikir logis, analitis, sistematis, kritis, kreatif, dan kemampuan bekerja sama. Dalam mempelajari matematika ada beberapa kemampuan yang perlu dimiliki siswa, salah satunya yaitu kemampuan pemecahan masalah.

Pentingnya kemampuan pemecahan masalah ditegaskan dalam National Council of Teachers of Mathematics (NCTM) tahun 2010 yang menyatakan bahwa dalam pembelajaran matematika, pemecahan masalah merupakan bagian integral dalam pembelajaran matematika sehingga hal tersebut tidak boleh dilepaskan dari pembelajaran matematika. Pemecahan masalah bukan hanya menjadi tujuan dalam pembelajaran matematika, melainkan bagian utama dari segala aspek aktivitasnya. Hal ini sejalan dengan tingkat kompetensi pengetahuan untuk pendidikan menengah yang harus dimiliki siswa dalam rangka mencapai standar kompetensi lulusan dan menerapkan pengetahuan pada bidang kajian yang spesifik sesuai dengan bakat dan minatnya untuk memecahkan masalah (Depdikbud, 2016).

Setiap siswa diharapkan mampu menerapkan pengetahuannya untuk memecahkan masalah, baik masalah dalam pembelajaran matematika maupun masalah dalam kehidupan sehari-hari. Dalam kehidupan sehari-hari secara sadar maupun tidak sadar, kita dihadapkan dengan berbagai permasalahan yang menuntut kemampuan pemecahan masalah. Namun, kenyataannya kemampuan pemecahan masalah siswa masih jauh dari harapan.

Siswa terbiasa mengerjakan soalsoal sejenis yang sudah diterangkan oleh guru yang membuat siswa kurang melatih kemampuan pemecahan masalahnya. Selain itu, kesulitan yang sering dialami siswa yaitu kurangnya pemahaman siswa terhadap masalah, kesalahan siswa dalam menginterpretasikan kondisi-kondisi masalah, ketidaktepatan strategi yang digunakan untuk memecahkan masalah matematika, ketidakmampuan siswa dalam menerjemahkan masalah dalam bentuk matematika, kesalahan perhitungan.

Berdasarkan uraian di atas, salah satu upaya yang dapat dilakukan dalam mengatasi hal tersebut yaitu dengan memaksimalkan atau melakukan inovasi terkait model pembelajaran yang diterapkan. Sehubungan dengan hal tersebut, maka salah satu alternatif model pembelajaran yang dapat diterapkan yaitu model pembelajaran MASTER. Model pembelajaran MASTER merupakan bagian dari cara belajar cepat (accelerated learning) dan diajukan pertama kali oleh Jayne Nicholl (Rose, 2002). Keterampilan belajar cepat dan berpikir jernih merupakan dua keterampilan personal kunci untuk dapat hidup layak di abad ke-21. Kedua keterampilan itu akan menghasilkan kemandirian dan kepercayaan diri. Metode belajar cepat ini akan mengeluarkan kemampuan terpendam dalam diri manusia. Intinya, metode ini mengakui bahwa masing-masing dari kita memiliki cara belajar pribadi pilihannya yang cocok dengan karakter dirinya.

Seseorang yang belajar menggunakan teknik-teknik yang cocok dengan gaya belajar pribadinya, maka seseorang tersebut dapat belajar dengan cara paling alamiah bagi dirinya sendiri. Sebab, yang alamiah menjadi lebih mudah, dan yang lebih mudah menjadi lebih cepat. Itulah sebabnya, kenapa metode ini disebut dengan cara belajar cepat. Struktur metode cara belajar cepat dibagi menjadi enam langkah dasar. Keenam langkah tersebut dapat diingat dengan mudah yang disingkat menjadi MASTER. Rossitha (2014:20) menyatakan model pembelajaran MASTER merupakan suatu model pembelajaran yang terdiri dari enam tahapan efektif yang dapat membantu seseorang lebih mudah dalam memperoleh informasi dan mengingat informasi. Siswa akan belajar lebih baik apabila siswa berada dalam lingkungan tanpa stress, melihat manfaat dari subjek pembelajaran, merasa tertantang untuk berpikir jauh ke depan, dan mampu mengeksplorasi apa yang dipelajari untuk memahami pelajaran (Rose,2002). 
Semua cara-cara di atas, terangkum dalam enam tahapan efektif pada model pembelajaran MASTER yang merupakan akronim dari (1) Motivating your mind (memotivasi pikiran), (2) Acquiring the information (memperoleh informasi) (3) Searching out the meaning (menyelidiki makna) (4) Triggering the memory (memicu memori), (5) Exhibiting what you know (memamerkan apa yang diketahui), (6) Reflecting how you have learned (merefleksikan cara belajar). Penerapan model pembelajaran MASTER akan memperbaiki proses pembelajaran di kelas sehingga siswa dapat melatih kemampuan pemecahan masalahnya selama proses pembelajaran. Dengan menerapkan model pembelajaran MASTER, siswa diajak untuk menemukan sendiri makna dari suatu permasalahan ataupun materi yang sedang dipelajari. Siswa diarahkan untuk aktif mengonstruksi pengetahuannya supaya menemukan makna dari permasalahan yang diberikan sehingga memahami apa sebenarnya konsepkonsep kunci pada permasalahan yang diberikan.

Terdapat keterkaitan antara model pembelajaran MASTER dengan indikator kemampuan pemecahan masalah. Holmes (Wardhani, 2010:35) menyatakan bahwa strategi pemecahan masalah yang terkenal adalah strategi pemecahan masalah dari Polya. Strategi Polya memiliki empat langkah rencana pemecahan masalah yang baik untuk menyelesaikan masalah rutin maupun tidak rutin. Adapun empat langkah pemecahan masalah dari Polya yaitu: 1) memahami masalah (understanding the problem), 2) menyusun rencana (devising a plan), 3) melaksanakan rencana (carrying out the plan), dan 4) memeriksa hasil yang diperoleh (looking back). Selain itu, dengan berbantuan mind mapping dapat memaksimalkan langkah-langkah pada model pembelajaran MASTER.

Model pembelajaran MASTER berbantuan mind mapping memiliki keterkaitan dengan indikator kemampuan pemecahan masalah dapat dilihat mulai dari tahap Acquiring the information (memperoleh informasi) artinya dalam tahap ini guru dalam pembelajaran harus memberikan informasi kepada siswa yang berkaitan dengan pembelajaran, hal tersebut akan efisien dengan memberikan mind mapping. Mind mapping yang diberikan berupa informasi umum dari materi yang akan dipelajari. Pada langkah ini siswa juga harus mengingat dan mendalami materi sebelumnya atau pengetahuan awal yang relevan dengan materi yang akan dipelajari. Mind mapping mempermudah siswa atau membuat siswa lebih cepat memperoleh informasi penting yang harus dimiliki. Penggunaan mind mapping sangat bermanfaat dalam pembelajaran, pernyataan ini sejalan dengan penelitian yang telah dikakukan oleh Fitri Arif Kholidah (2017) yang berjudul "Peningkatan Pemahaman Konsep Matematika pada Materi Bangun Ruang dengan Model Pembelajaran Mind Mapping". Dari penelitian ini memberikan kesimpulan bahwa penerapan Mind Mapping dapat meningkatkan pemahaman konsep bangun ruang pada siswa kelas VIII D SMP Negeri 7 Sukoharjo tahun ajaran 2016/2017. Setelah menerima informasi pada tahap Acquiring the information (memperoleh informasi) siswa diharapkan mampu memahami masalah yang disajikan dalam pembelajaran (understanding the problem).

Pada tahap selanjutnya yaitu Searching out the meaning (menyelidiki makna) yaitu setelah siswa mendapatkan informasi langkah selanjutnya guru harus membimbing siswa untuk menyelidiki apakah informasi yang diberikan dapat memberikan manfaat dalam pembelajaran atau menyelidiki makna berdasarkan informasi yang telah diperoleh di suatu permasalahan dalam pemebelajaran. Informasi-informasi yang diselidiki siswa akan dijadikan bahan untuk menyusun rencana yang tepat dalam menyelesaikan suatu permasalah yang diberikan dalam suatu pembelajaran (devising a plan) dan kemudian dapat melaksanakan rencana tersebut (carrying out the plan). Tahap berikutnya adalah Triggering the memory (memicu memori), dalam tahap ini siswa diberikan pengulangan materi karena sebagai upaya menyimpan ingatan mengenai materi pembelajaran tersebut dalam jangka waktu yang lama, kegiatan ini 
sama dengan kegiatan mengingat kembali atau mengulang langkah demi langkah yang telah dibuat untuk memperkuat ingatan mengenai pembelajaran tersebut. Pada tahap ini siswa diberikan kesempatan untuk mengembangkan mind mapping berdasarkan konsep yang telah dipahami. Seiring dengan hal tersebut, maka secara tidak langsung siswa akan memeriksa kembali hasil yang telah diperoleh (looking back).

Model pembelajaran MASTER juga telah diterjemahkan dalam istilah KUASAI dan beberapa penelitian mengenai model pembelajaran KUASAI telah dilakukan yang menunjukkan bahwa model pembelajaran KUASAI memberikan pengaruh yang baik terhadap berbagai kegiatan pembelajaran. Salah satu kajian yang mendukung penerapan model ini adalah Dwijayani (2013) dalam penelitiannya terkait implementasi model pembelajara KUASAI di kelas XI IPA3 SMA Negeri 1 Kuta Utara menyatakan bahwa Implementasi model pembelajaran KUASAI dapat meningkatkan pemahaman konsep siswa.

Berdasarkan pemaparan di atas, penulis mencoba untuk melihat pengaruh yang ditimbulkan terhadap kemampuan pemecahan masalah matematika siswa yang dibelajarkan dengan model pembelajaran MASTER berbantuan mind mapping.

\section{METODE}

Penelitian ini merupakan penelitian eksperimen semu (quasi experiment), karena tidak seluruh variabelnya diatur dan dikontrol secara ketat. Rancangan penelitian ini menggunakan post test only control group design, artinya pada pertemuan terakhir kedua kelompok tersebut akan diberikan tes yang sama (post-test), selanjutnya skor dari post-test tersebut digunakan sebagai pedoman dalam melakukan uji hipotesis.

Populasi dalam penelitian ini adalah seluruh siswa kelas XI MIPA SMA Negeri 3 Singaraja tahun pelajaran 2018/2019 yang terdiri dari 3 kelas. Sebelum dilakukan penarikan sampel, diuji terlebih dahulu kesetaraan populasi untuk mengetahui bahwa populasi tersebut memiliki kemampuan yang setara atau tidak dengan syarat bahwa populasi berdistribusi normal dan bersifat homogen. Data yang digunakan sebagai dasar pengujian kesetaraan pada penelitian ini adalah nilai ulangan umum kelas XI MIPA SMA Negeri 3 Singaraja tahun ajaran 2018/2019. Uji kesetaraan ini dilakukan menggunakan uji analisis varians yaitu uji- $F$.

Sampel yang digunakan diperoleh dengan melakukan penarikan sampel yaitu memilih dua kelas dari tiga kelas yang ada dengan teknik cluster random sampling yaitu pemilihan sampel yang dilakukan secara acak tanpa memperhatikan strata yang ada dalam populasi tersebut dan diperoleh kelas XI MIPA 2 dan XI MIPA 3. Dua kelas yang terpilih, diundi kembali untuk menentukan kelompok kontrol dan kelompok eksperimen. Berdasarkan hasil pengundian, terpilih kelas XI MIPA 2 sebagai kelompok eksperimen dan kelas XI MIPA 3 sebagai kelompok kontrol.

Terdapat dua jenis variabel yang terlibat dalam penelitian ini, yaitu variabel bebas (independent variable) dan variabel terikat (dependent variable). Variabel bebas dalam penelitian ini adalah model pembelajaran, dimana model pembelajaran MASTER berbantuan mind mapping diterapkan pada kelas eksperimen dan model pembelajaran konvensional diterapkan pada kelas kontrol. Variabel terikat dalam penelitian ini adalah kemampuan pemecahan masalah matematika siswa kelas XI MIPA SMA Negeri 3 Singaraja. Rancangan penelitian ini dapat dilihat pada Tabel 1. Instrumen penelitian adalah alat yang digunakan oleh peneliti untuk mengumpulkan data (Arikunto, 2010). Instrumen yang digunakan dalam penelitian ini berupa tes kemampuan pemecahan masalah yang berbentuk uraian (essay). Kemampuan pemecahan masalah matematika siswa diukur dari kemampuan siswa memahami masalah, membuat rencana penyelesaian, melaksanakan rencana penyelesaian, dan memeriksa kembali pekerjaannya. Instrumen yang baik harus memenuhi dua persyaratan penting yaitu valid dan reliabel.

Uji coba instrumen penelitian dilakukan untuk mendapatkan gambaran secara empirik apakah instrumen 
Tabel 1. Rancangan Penelitian

\begin{tabular}{lcc}
\hline Kelompok & Perlakuan & Post test \\
\hline Eksperimen & $X_{1}$ & $Y_{1}$ \\
Kontrol & $X_{2}$ & $Y_{2}$ \\
\hline \multicolumn{2}{r}{ (dimodifikasi dari Sugiyono, 2012) }
\end{tabular}

Keterangan:

$X_{1}=$ Perlakuan berupa penerapan model pembelajaran MASTER berbantuan mind mapping

$X_{2}=$ Perlakuan berupa penerapan pembelajaran konvensional

$Y_{1}=$ post-test untuk kelas eksperimen

$Y_{2}=$ post-test untuk kelas kontrol

penelitian berupa tes kemampuan pemecahan masalah matematika siswa layak digunakan sebagai instrumen. Sebelum diberikan kepada siswa yang menjadi sampel penelitian, akan dilakukan beberapa uji terhadap instrumen penelitian untuk mendapatkan tes yang baik. Pertama akan dilakukan uji pakar/ahli untuk mengetahui validitas isi instrumen. Validitas isi dilakukan oleh dua orang pakar yang merupakan dosen di Jurusan Matematika Undiksha.

Perhitungan validitas isi dilakukan dengan formula Gregory dan dari hasil perhitungan diperoleh koefisien validitas isi tes kemampuan pemecahan masalah yang akan diujicobakan adalah 1,00 yang berarti tes kemampuan yang akan diujicobakan sangat relevan. Selanjutnya, tes kemampuan pemecahan masalah matematika diuji coba pada kelas XI MIPA 3 SMA Negeri 2 Singaraja dengan total soal yang diuji cobakan adalah 8 butir soal dan hasilnya digunakan untuk menghitung validitas dan reliabilitas instrumen tersebut.

"Validitas tes merupakan tingkat suatu tes mampu mengukur apa yang hendak diukur" (Arikunto, 2012:144). Salah satu cara untuk mencari koefisien validitas alat evaluasi yang berbentuk uraian adalah dengan menggunakan koefisien korelasi product-moment dari Carl Pearson (Candiasa, 2010b). Berdasarkan hasil analisis validitas tes uji coba diperoleh 8 butir soal valid. Selanjutnya, butir soal yang valid diuji reliabilitasnya. "Reliabilitasnya tes mengacu pada tingkat keterandalan tes tersebut sebagai instrument penelitian" (Arikunto, 2012:154). Untuk menentukan reliabilitas instrumen bentuk essay (uraian) dapat menggunakan rumus Alpha Cronbach (Candiasa, 2010a).

Berdasarkan hasil analisis reliabilitas tes, diperoleh koefisien reliabilitasnya adalah 0,521 . Hasil tersebut menunjukkan bahwa tes uji coba kemampuan pemecahan masalah matematika siswa reliabel dengan reliabilitas sedang, sehingga soal-soal tersebut layak untuk digunakan. Dari delapan butir soal yang valid dan reliabel dipilih lima butir soal yang digunakan sebagai tes kemampuan pemecahan masalah matematika siswa, sebab kelima soal tersebut sudah mencakup keseluruhan materi yang diajarkan.

Data kemampuan pemecahan masalah matematika yang telah diperoleh perlu diuji dengan uji prasyarat yaitu uji normalitas dan uji homogenitas. Setelah semua uji prasyarat tersebut terpenuhi selanjutnya dilakukan uji hipotesis untuk memperoleh kesimpulan dari penelitian yang telah dilakukan dengan menggunakan uji-t satu ekor.

\section{HASIL DAN PEMBAHASAN}

Rangkuman analisis terhadap skor kemampuan pemecahan masalah matematika siswa pada kelompok eksperimen dan kelompok kontrol dapat dilihat pada Tabel 2. Pengujian normalitas sebaran data pada penelitian ini dilakukan dengan menggunakkan uji Liliefors pada taraf signifikan 5\%. Hasil analisis uji normalitas pada kelompok eksperimen 
Tabel 2. Rangkuman Analisis terhadap Data Kemampuan Pemecahan Masalah Matematika Siswa

\begin{tabular}{ccc}
\hline \multirow{2}{*}{ Variabel } & \multicolumn{2}{c}{ Post-test } \\
\cline { 2 - 3 } & $\begin{array}{c}\text { Kelompok } \\
\text { Eksperimen }\end{array}$ & $\begin{array}{c}\text { Kelompok } \\
\text { Kontrol }\end{array}$ \\
\hline $\mathrm{N}$ & 33 & 32 \\
Mean & 78,90909 & 68,6875 \\
Varians & 127,5227 & 133,5121 \\
$S D$ & 11,2926 & 11,55474 \\
Maximum & 96 & 86 \\
Minimum & 58 & 40 \\
\hline
\end{tabular}

dengan data sebanyak 33 , menunjukkan bahwa nilai $L_{\text {hitung }}$ sebesar 0,09331 dan nilai $L_{\text {tabel }}$ sebesar 0,150751 . Sedangkan, pada kelompok kontrol dengan data sebanyak 32, menunjukkan bahwa $L_{\text {hitung }}$ sebesar 0,079782 dan $L_{\text {tabel }}$ sebesar 0,153089 . Terlihat bahwa pada kelompok eksperimen maupun kelompok kontrol menunjukkan nilai $L_{\text {hitung }}<L_{\text {tabel }}$. Ini berarti, data kemampuan pemecahan masalah matematika siswa berasal dari populasi yang berdistribusi normal. Analisis data dilanjutkan dengan melakukan pengujian homogenitas varians. Pada penelitian ini, pengujian varians dilakukan dengan menggunakkan uji- $F$ dan diperoleh $F_{\text {hitung }}=$ 1,046967. Berdasarkan tabel untuk taraf signifikan $5 \%, d k$ pembilang $=31$ dan $d k$ penyebut $=32$, diperoleh $F_{\text {tabel }}=F_{(0,05),(31,32)}$ $=$ 1,810479. Karena $F_{\text {hitung }}<F_{\text {tabel }}$, ini berarti data kemampuan pemecahan masalah matematika siswa mempunyai varians yang homogen.

Berdasarkan hasil uji normaltas dan homogenitas varians, diperoleh bahwa sebaran data kemampuan pemecahan masalah matematika siswa pada kelompok eksperimen dan kelompok kontrol berdistribusi normal, serta memiliki varians yang homogen. Selanjutnya dilakukan uji hipotesis dengan menggunakkan uji-t satu ekor pada taraf signifikan $5 \%$. Rangkuman hasil analisis uji-t dapat dilihat pada Tabel 3. Berdasarkan Tabel 3, menunjukkan bahwa $t_{\text {hitung }}>t_{\text {tabel }}$. Ini berarti, kemampuan pemecahan masalah matematika siswa
Tabel 3. Rangkuman Hasil Uji- $t$

\begin{tabular}{ccc}
\hline \multirow{2}{*}{ Variabel } & \multicolumn{2}{c}{ Post-test } \\
\cline { 2 - 3 } & $\begin{array}{c}\text { Kelompok } \\
\text { Eksperimen }\end{array}$ & $\begin{array}{c}\text { Kelompok } \\
\text { Kontrol }\end{array}$ \\
\hline$N$ & 33 & 32 \\
$d k$ & 63 & 63 \\
$\bar{X}$ & 78,90909 & 68,6875 \\
$S D$ & 11.2926 & 11.55474 \\
$t_{\text {hitung }}$ & \multicolumn{2}{c}{3,606938} \\
$t_{\text {tabel }}$ & \multicolumn{2}{c}{1.998341} \\
\hline
\end{tabular}

yang dibelajarkan dengan model pembelajaran MASTER berbantuan mind mapping lebih baik daripada kemampuan pemecahan masalah matematika siswa yang dibelajarkan dengan model pembelajaran konvensional.

Terjadinya hal tersebut sebab pembelajaran dengan model pembelajaran MASTER memberikan siswa kesempatan untuk berpartisipasi dalam menyelesaikan suatu masalah dan menemukan suatu konsep dengan kondisi pikiran yang relaks, percaya diri dan termotivasi. Langkahlangkah pembelajaran MASTER menuntut siswa untuk aktif menemukan sendiri makna dari permasalahan ataupun materi yang sedang dipelajari. Peningkatan sangat jelas terlihat pada saat siswa sudah mandiri dalam belajar, siswa aktif berdiskusi dengan kelompoknya dan siswa sudah bisa berkomunikasi dalam menyampaikan pendapat ataupun memberi tanggapan. Pembuatan mind map juga meningkatkan minat siswa untuk belajar matematika.

Terdapat enam langkah dalam model pembelajaran MASTER yakni (1) Motivating your mind (memotivasi pikiran), (2) Acquiring the information (memperoleh informasi) (3) Searching out the meaning (menyelidiki makna) (4) Triggering the memory (memicu memori), (5) Exhibiting what you know (memamerkan apa yang diketahui), (6) Reflecting how you have learned (merefleksikan cara belajar). Pada langkah pertama Motivating your mind (memotivasi pikiran), guru memberikan motivasi terhadap siswa di awal pembelajaran. Motivasi yang dimaksudkan adalah menyampaikan bagaimana manfaat dalam mempelajari matematika yang dapat berguna dalam kehidupan sehari-hari. 
Langkah berikutnya adalah Acquiring the information (memperoleh informasi), siswa dihadapkan dengan pertanyaan-pertanyaan pancingan untuk mengingatkan siswa terhadap materi sebelumnya, pada langkah ini pula digunakan bantuan mind mapping untuk mempermudah memetakan informasi yang ingin disampaikan dan guru akan membantu siswa memberikan gambaran umum (belum lengkap) terkait materi yang akan diipelajarin. Dengan mengingat pengetahuan awal, siswa akan belajar mengaitkan pengetahuan yang sudah dimiliki dengan pengetahuan baru. Langkah selanjutnya adalah Searching out the meaning (menyelidiki makna), pada langkah ini guru memberikan LKS dan memberikan kesempatan kepada setiap siswa untuk berperan aktif dalam menyelesaikan permasalahan yang terdapat pada LKS. Setelah selesai mengerjakan LKS, pada langkah Triggering the memory (memicu memori), siswa diminta untuk mengembangkan mind mapping nya sendiri terkait konsep-konsep kunci yang diperoleh selama kegiatan pembelajaran. Melalui pembuatan mind mapping ini, siswa akan mengingat lebih lama konsep-konsep penting yang harus mereka pahami.

Pada langkah Exhibiting what you know (memamerkan apa yang diketahui), guru memberikan kesempatan pada salah satu siswa sebagai perwakilan untuk mempresentasikan hasil belajarnya, pada langkah ini dapat terlihat bahwa siswa telah benar-benar mampu mempelajari pembelajaran yang telah diberikan, selain itu pada langkah ini siswa juga diberikan kesempatan untuk memberikan umpan balik seperti bertanya maupun menanggapi hasil belajar yang telah dibuat oleh siswa lainnya. Akibatnya siswa akan menjadi lebih berani untuk mengungkapkan pendapatnya maupun bertanya terkait materi yang belum dipahami. Langkah yang terakhir adalah Reflecting how you have learned (merefleksikan cara belajar), guru dan siswa melakukan refleksi terhadap kegiatan pembelajaran yang sudah berlangsung. Siswa diberikan kesempatan untuk bertanya apa yang masih belum dimengerti serta kendala- kendala yang mengganggu siswa selama pembelajaran berlangsung. Selain itu, pada tahap ini pula dapat diberikan kuis atau pekerjaan rumah untuk dijadikan bahan evaluasi terhadap proses pembelajaran.

$$
\text { Pada proses pembelajaran }
$$
menggunakan model pembelajaran MASTER berbantuan mind mapping, peran guru sebagai fasilitator dan mediator dalam pembelajaran, sementara siswa didorong untuk belajar aktif dan kreatif dalam kegiatan pembelajaran mulai dari menemukan solusi dari permasalahan, diskusi kelompok dan presentasi hasil diskusi. Akibatnya, siswa mampu mengkontruksi sendiri suatu pengetahuan atau suatu konsep, melalui pengintegrasian secara aktif pengetahuan baru dengan menggunakan pengetahuan yang sudah dimiliki sebelumnya. Secara bertahap kemampuan pemecahan masalah matematika siswa pada kelompok eksperimen mengalami perkembangan yang baik dibandingkan siswa pada kelompok kontrol yang dibelajarkan dengan model pembelajaran konvensional.

\section{SIMPULAN DAN SARAN}

Berdasarkan rumusan masalah, tujuan, hasil analisis, dan pembahasan yang telah diuraikan di depan, dapat disimpulkan bahwa kemampuan pemecahan masalah matematika siswa kelas XI MIPA SMA Negeri 3 Singaraja yang dibelajarkan dengan model pembelajaran MASTER berbantuan mind mapping lebih baik daripada kemampuan pemecahan masalah matematika siswa yang dibelajarkan dengan model pembelajaran konvensional.

Berdasarkan hasil penelitian yang telah dilakukan, peneliti melalui tulisan ini menyampaikan beberapa saran sebagai berikut.

1. Kepada praktisi pendidikan, khususnya pihak-pihak yang terlibat dalam pembelajaran matematika disarankan untuk menggunakan model pembelajaran MASTER berbantuan mind mapping sebagai salah satu alternative pembelajaran di kelas.

2. Penelitian ini dilakukan pada sampel dan materi pembelajaran yang terbatas. 
Para peneliti lain yang tertarik disarankan untuk melakukan penelitian terhadap model pembelajaran MASTER berbantuan mind mapping dengan sampel yang lebih besar dan materi pembelajaran yang lebih luas untuk mengetahui pengaruh penerapan model pembelajaran ini dalam pembelajaran matematika secara lebih mendalam.

\section{DAFTAR PUSTAKA}

Arikunto, S. 2010. Prosedur Penelitian Suatu Pendekatan Praktik. Jakarta: Rineka Cipta

Arikunto, S. 2012. Dasar-Dasar Evaluasi Pendidikan. Jakarta: Bumi Aksara.

Candiasa, I Made. 2010a. Pengujian Instrumen Penelitian Disertai Aplikasi ITEMAN dan BIGSTEPS. Singaraja: Universitas Pendidikan Ganesha.

2010b. Statistik Univariat dan Bivariat Disertai Aplikasi SPSS. Singaraja: Universitas Pendidikan Ganesha.

Daryanto dan Mulyo Rahrdjo. 2012. "Model Pembelajaran Inovatif". Yogyakarta: Gava Media.

Depdikbud .2016. Permendikbud No 21 Tahun 2016 Tentang Standar Isi Pendidikan Dasar dan Menengah. Jakarta : Depdikbud.

Dwijayani, Ni Made. 2013. "Implementasi Model Pembelajaran KUASAI untuk Meningkatkan Pemahaman Konsep Matematika Siswa Kelas XI IPA3 SMA Negeri 1 Kuta Utara". Skripsi (tidak diterbitkan). Jurusan Pendidikan Matematika, UNDIKSHA.

Kholidah, Fitri Arif. 2017. "Peningkatan Pemahaman Konsep Matematika Pada Materi Bangun Ruang dengan Model Pembelajaran Mind Mapping". Skripsi. Program Studi Matematika, Universitas Muhamadiyah Surakarta.
Rose, Colin dan Malcolm J. Nicholl. 2002. Cara Belajar Cepat Abad XXI. Terjemahan Dedy Ahimsa. Accelarated Learning For The 21th Century. 1997. Jakarta: Yayasan Nuansa Cendekia.

Rossitha, Putu Intan. 2014. "Pengaruh Penerapan Model pembelajaran KUASAI terhadap Penghargaan Diri dan Kemampuan Koneksi Matematis Siswa Kelas VII SMP Negeri 5 Singaraja". Skripsi (tidak diterbitkan). Jurusan Pendidikan Matematika, Undiksha.

Sundayana. 2014. Media dan Alat Peraga dalam Pembelajaran Matematika. Bandung: Alfabeta.

Sugiyono. 2012. Metode Penelitian Pendidikan. Bandung : Alfabeta.

Wardhani, S. dkk. 2010. Pembelajaran Kemampuan Pemecahan Masalah Matematika di SD. Yogyakarta: PPPPTK Matematika 